\title{
FREKUENSI MOLTING DAN SINTASAN LOBSTER AIR TAWAR (Cherax quadricarinatus) DENGAN PERSENTASE PAKAN TUBIFEX DAN KOMERSIAL YANG BERBEDA
}

\author{
Sarmin ${ }^{1}$, Marhaendro Santoso ${ }^{2}$, \& Kasprijo ${ }^{3}$ \\ 1) Fakultas Sains dan Teknologi, Prodi IImu Perikanan, Universitas Nahdlatul Ulama Purwokerto, Jl. \\ Sultan Agung No.42 Karangklesem, Purwokerto, Telp. (0281) 6841836, email: \\ sarminaljabar@yahoo.co.id \\ 2,3) Fakultas Perikanan dan Kelautan, Prodi Budidaya Perairan, Universitas Jenderal Soedirman Purwokerto, \\ Jl. Dr. Suparno, Karangwangkal, Purwokerto, Tlp. (0281) 6596700, email: marhaendrosantoso@gmail.com, \\ email: kaspriyo37@yahoo.com
}

\begin{abstract}
Abstrak
Pakan merupakan komponen dalam budidaya yang sangat besar peranannya dari segi penentu pertumbuhan maupun dari segi biaya produksi, mengingat bahwa Lobster Air Tawar termasuk hewan omnivora yang dapat diberi pakan tubifex dan pakan komersial. Penelitian ini mengkaji pengaruh pakan tubifex dan komersial terhadap frekuensi molting dan sintasan Lobster Air Tawar. Penelitian ini dilaksanakan selama 60 hari, hewan uji memiliki berat rata-rata $3 \pm 0,69 \mathrm{~g}$ dan panjang rata-rata $5 \pm 0,34 \mathrm{~cm}$. Rancangan percobaan menggunakan Rancangan Acak Lengkap (RAL) dengan lima perlakuan dan empat ulangan. Perlakuan $\mathrm{P} 1=0 \%$ pakan tubifex dan $100 \%$ komersial, $\mathrm{P} 2=25 \%$ tubifex dan $75 \%$ komersial, $\mathrm{P} 3=50 \%$ tubifex dan $50 \%$ komersial, $\mathrm{P} 4=75 \%$ tubifex dan $25 \%$ komersial, P5 $=100 \%$ tubifex dan $0 \%$ komersial. Hasil penelitian menunjukan bahwa frekuensi molting dan sintasan tidak berbeda nyata antar perlakuan. Nilai frekuensi molting antar perlakuan berturut-turut $\mathrm{P} 1=4,25 \pm 1,5$ kali; $\mathrm{P} 2=3,75 \pm 1,5$ kali; $\mathrm{P} 3=2,75 \pm 1,3$ kali; $\mathrm{P} 4=4 \pm 1,4$ kali; $\mathrm{P} 5=3,5 \pm 1,3$ kali. Nilai sintasan antar perlakuan berturut-turut $\mathrm{P} 1=40 \pm 16,33 \% ; \mathrm{P} 2=30 \pm 25,82 \% ; \mathrm{P} 3=35 \pm 25,17 \% ; \mathrm{P} 4=30 \pm 25,82 \%$ dan $\mathrm{P} 5=45 \pm 25,82 \%$.
\end{abstract}

Kata kunci: Cherax quadricarinatus, molting, pakan komersial, sintasan, tubifex.

\section{Abstract}

Feeding is one component in the cultivation which plays a very large role in growth determination and in terms of production costs, given that freshwater crayfish is omnivorous that can be fed with commercial and tubifex feed. This study examines the influence of a combination of commercial and tubifex feed on moulting frequency and survival rate of freshwater crayfish. The research was conducted for 60 days; tested animals weighed $3 \pm 0.69 \mathrm{~g}$ and measured $5 \pm 0.34 \mathrm{~cm}$, in average. Experimental design using Complete Randomized Design (CRD) was applied to examine 5 treatments in quadruplicates. Treatment $P 1$ represented $0 \%$ tubifex and $100 \%$ commercial feed, $P 2=25 \%$ tubifex and $75 \%$ commercial feed, $P 3=50 \%$ tubifex and $50 \%$ commercial feed, $P 4=75 \%$ tubifex and $25 \%$ commercial feed, $P 5=100 \%$ tubifex and $0 \%$ commercial feed. The study showed that the survival rate and moulting frequency were not different between treatments. Moulting frequency between successive treatment were $P 1=4.25 \pm 1.5, P 2=1.5 \pm 3.75, P 3=2.75 \pm 1.3, P 4=$ $4 \pm 1.4, P 5=3.5 \pm 1$.3. Survival rate between respective treatment were $P 1=40 \pm 16.33 \%, P 2=30 \pm 25.82 \%, P 3=$ $35 \pm 25.17 \%, P 4=30 \pm 25.82 \%$, and $P 5=45 \pm 25.82 \%$.

Key words: Cherax quadricaritanus, feed, molting, survival, tubifex.

\section{PENDAHULUAN}

Lobster Air

quadricarinatus) atau sering disebut capit merah (red claw), merupakan komoditas perairan tawar yang mempunyai nilai ekonomis. Lobster Air Tawar merupakan spesies asli Australia, dan sudah dibudidayakan secara komersial di Australia. Lobster Air Tawar mulai dibudidayakan di
Indonesia pada tahun 2000 (Sukmajaya dan Suharjo, 2003).

Lobster Air Tawar ukuran konsumsi mempunyai permintaan pasar yang tinggi tetapi jumlahnya belum bisa mencukupi permintaan tersebut. Harga Lobster Air Tawar ukuran $100 \mathrm{~g}$ di dalam negeri pada awal tahun 2007 mencapai Rp. 125.000/kg (Lukito dan Prayugo, 2007). Hal ini disebabkan oleh laju 
pertumbuhan yang lambat, untuk mencapai ukuran konsumsi 50-150 g diperlukan pemeliharaan 6-12 bulan, bahkan untuk mencapai ukuran $300 \mathrm{~g}$ dibutuhkan pemeliharaan selama 2 tahun (Pinto dan Rouse, 1996). Untuk mengatasi kendala tersebut maka dibutuhkan pakan yang berkualitas selama masa pemeliharaan. Salah satu upaya agar pertumbuhan Lobster Air Tawar optimal yaitu dengan pemilihan pakan yang tepat.

Lobster Air Tawar adalah hewan omnivora pemakan tumbuh-tumbuhan, molusca kecil seperti siput, vertebrata kecil, dan detritus (Nystrom, 2002). Pakan yang baik adalah pakan dengan kandungan nutrisi sesuai dengan kebutuhan Lobster Air Tawar berupa protein, karbohidrat, lemak, vitamin, dan mineral. Pakan yang baik dapat mendukung pertumbuhan Lobster Air Tawar hal ini dapat menjadikan sehat, kuat, dan terhindar dari serangan penyakit (Setyogati, 2006).

Kandungan protein dalam pakan harus tepat. Kekurangan protein dalam pakan dapat menyebabkan kondisi organisme akuatik terganggu sehingga dapat menghambat pertumbuhan, tetapi semakin tinggi kandungan protein dalam pakan maka pertumbuhannya semakin baik. Selain itu, nutrisi dan keberhasilan molting memiliki peranan penting dalam pertumbuhan Lobster Air Tawar (Nainggolan, 2008).

Peran molting sangat penting dalam pertumbuhan Lobster Air Tawar, karena Lobster Air Tawar hanya bisa tumbuh melalui molting (Ahvenharju, 2007). Semakin sering Lobster Air Tawar melakukan molting, maka pertumbuhannya juga semakin baik (Hakim, 2009). Faktor yang mempengaruhi pertumbuhan dan sintasan Lobster Air Tawar adalah kualitas benih, jenis pakan, kualitas air, penyakit, dan keberhasilan molting. Keberhasilan molting sendiri sangat tergantung pada cadangan kalsium dalam tubuh Lobster Air Tawar. Banyak kematian
Lobster Air Tawar yang disebabkan oleh ketidakmampuannya dalam melakukan molting secara sempurna. Salah satu penyebab kegagalan molting adalah tidak berhasilnya Lobster Air Tawar dalam proses gastrolisasi, yaitu penyerapan kalsium yang ada di dalam tubuhnya.

Penelitian frekuensi molting dan sintasan Lobster Air Tawar dengan persentase pakan tubifex dan komersial yang berbeda, diharapkan dapat meningkatkan pertumbuhan dan sintasan, sehingga mampu meningkatkan produksi Lobster Air Tawar.

\section{BAHAN DAN METODE}

\section{Bahan}

Alat yang digunakan dalam penelitian ini adalah akuarium kaca sebanyak 20 buah dengan ukuran $70 \times 40 \times 30 \mathrm{~cm}$, perlengkapan aerasi, timbangan elektrik dengan ketelitian $0,01 \mathrm{~g}, \mathrm{pH}$ meter, kertas label, paralon, thermometer air raksa, alat tulis, penggaris, dan milimeter blok. Bahan yang digunakan dalam penelitian ini adalah pakan komersial, tubifex, larutan $\mathrm{MnSO}_{4}, \mathrm{KOH}-\mathrm{KI}, \mathrm{H}_{2} \mathrm{SO}_{4} 4 \mathrm{~N}$, indikator amilum, dan $\mathrm{Na}_{2} \mathrm{~S}_{2} \mathrm{O}_{3} 0,025 \mathrm{~N}$.

\section{Metode}

\section{Desain Penelitian}

Penelitian ini dilaksanakan dengan metode eksperimental, menggunakan Rancangan Acak Lengkap (RAL) dengan 5 perlakuan dan 4 ulangan. Kandungan air cacing tubifex basah $87 \%, 1 \mathrm{~g}$ cacing tubifex basah menjadi $0,13 \mathrm{~g}$ kering dan kandungan air pakan komersial $12 \%$, pakan komersial $1 \mathrm{~g}$ menjadi $0,88 \mathrm{~g}$ kering. Perlakuan yang diujikan yaitu:

$$
\begin{aligned}
\mathrm{P} 1= & 0 \%(0 \mathrm{~g}) \text { pakan tubifex kering dan } 100 \% \\
& (0,45 \mathrm{~g}) \text { komersial kering. } \\
\mathrm{P} 2= & 25 \%(0,01 \mathrm{~g}) \text { pakan tubifex kering dan } \\
& 75 \%(0,33 \mathrm{~g}) \text { komersial kering } \\
\mathrm{P} 3= & 50 \%(0,02 \mathrm{~g}) \text { pakan tubifex kering dan } \\
& 50 \%(0,22 \mathrm{~g}) \text { komersial kering }
\end{aligned}
$$


$\mathrm{P} 4=75 \%(0,03 \mathrm{~g})$ pakan tubifex kering dan $25 \%(0,11 \mathrm{~g})$ komersial kering

$\mathrm{P} 5=100 \%(0,05 \mathrm{~g})$ pakan tubifex kering dan $0 \%(0 \mathrm{~g})$ komersial kering

\section{Persiapan Wadah Penelitian}

Wadah yang digunakan dalam penelitian ini adalah akuarium dengan volume $84 \mathrm{~L}$ berjumlah 20 buah. Akuarium dicuci terlebih dahulu sebelum digunakan dan diisi air dengan ketinggian $20 \mathrm{~cm}$. setelah itu ditambahkan shelter 5 buah ke dalam setiap akuarium.

\section{Pengadaan dan Penebaran Lobster}

Lobster Air Tawar yang disiapkan dalam penelitian ini sebanyak 500 ekor. Kemudian dipilih 100 ekor yang seragam dengan cara diukur panjang tubuhnya serta ditimbang beratnya. Padat penebaran sebanyak 5 ekor/56 L.

\section{Pemberian Pakan}

Jumlah pakan yang diberikan dalam penelitian ini sebanyak (0,05-0,45 g). Pakan yang diberikan berupa pakan tubifex dan pakan komersial dengan persentase berbeda sesuai dengan perlakuan. Pemberian pakan tubifex diberikan dalam bentuk kering sebagai pakan alami dan pakan komersial diberikan dalam keadaan kering sesuai keadaan aslinya sebagai pakan buatan. Pemberian pakan dilakukan setiap jam 17.00 dan penyiponan dilakukan setiap jam 07.00 untuk mengambil sisa pakan, karena tidak semua pakan tubifex dan komersial tersebut dikonsumsi.

\section{Frekuensi Molting}

Frekuensi molting adalah jumlah kejadian molting pada Lobster Air Tawar selama penelitian. Molting merupakan salah satu parameter pertumbuhan Lobster Air Tawar. Perhitungan frekuensi molting dilakukan dengan menghitung jumlah populasi Lobster Air Tawar yang melakukan molting sempurna selama penelitian 60 hari (Hakim, 2009).

\section{Sintasan}

Sintasan adalah persentase antara Lobster Air Tawar yang hidup pada akhir penelitian dengan jumlah yang ditebar pada awal penelitian. Pengamatan dilakukan setiap hari dengan menghitung Lobster Air Tawar yang mati pada setiap akuarium. Sintasan Lobster Air Tawar ditentukan dengan rumus (Effendi, 1997).

$$
S R=\frac{N t}{N o} X 100 \%
$$

SR : Persentase sintasan

Nt : Jumlah Lobster Air Tawar pada akhir penelitian

No : Jumlah Lobster Air Tawar pada awal penelitian

\section{Analisis Data}

Data yang diperoleh berupa Frekuensi molting dan sintasan ditransformasi arcsin terlebih dahulu antar perlakuan kemudian dianalisis dengan ANOVA menggunakan uji F. Hasil uji $F$ menunjukan hasil yang tidak berbeda nyata, maka tidak perlu dilakukan uji lanjut BNT.

\section{HASIL DAN PEMBAHASAN}

\section{Frekuensi Molting}

Berdasarkan analisis Variansi Frekuensi molting menunjukan hasil yang tidak berbeda nyata dimana $F$ hitung $<F$ tabel. Data selengkapnya dapat dilihat pada (Lampiran 2). Menurut Affandi dan Tang (2002), molting adalah suatu proses pelepasan secara periodik karapak yang sudah tua dan pembentukan yang baru dengan ukuran yang lebih besar. Peran molting sangat penting dalam pertumbuhan Lobster Air Tawar, karena hanya bisa tumbuh melalui molting (Ahvenharju, 2007). Semakin sering Lobster Air Tawar melakukan molting, maka pertumbuhannya juga semakin baik. Pakan merupakan sumber nutrisi dan energi yang dibutuhkan organisme untuk mepertahankan 
hidup, pertumbuhan, dan reproduksi (National Research Council, 1993).

Berdasarkan hasil penelitian frekuensi molting antar perlakuan tidak berbeda nyata. Hal ini diduga karena kandungan nutrisi pakan antar perlakuan masih sesuai untuk mendukung pertumbuhan Lobster Air Tawar yang optimal. Hal ini sesuai dengan pernyataan Webster et al., (1994), yang menjelaskan bahwa juvenil Lobster Air Tawar dengan bobot 0,2-1 g membutuhkan pakan dengan kandungan protein sekurangkurangnya 25\%. Manomaitis (2001), menyarankan bahwa benih Lobster Air Tawar dengan bobot lebih dari $1 \mathrm{~g}$ hendaknya diberi pakan dengan kandungan protein 30\% yang berfungsi untuk mempercepat pertumbuhan secara maksimal.

Pakan komersial diproses dari berbagai bahan yang jumlahnya sangat banyak (Zonneveld et al., 1991). Bahan-bahan yang digunakan sebagai pembuat pakan komersial tersebut merupakan bahan pilihan yang sudah diperhitungkan, sehingga kebutuhan nutrisi yang dibutuhkan untuk tumbuh sudah terdapat dalam pakan komersial yang diberikan. Mengingat pakan merupakan salah satu komponen dalam budidaya yang sangat besar peranannya sebagai faktor penentu pertumbuhan maupun dari segi biaya produksi (Affandi dan Tang, 2002).

Cacing tubifex adalah salah satu pakan alami yang memiliki kandungan nutrisi penting seperti lemak $13,3 \%$ dan protein $57 \%$ (Subandiyah et al., (2003). Cacing tubifex memiliki kandungan protein yang melebihi kebutuhan protein Lobster Air Tawar, sebaliknya kandungan karbohidratnya sangat rendah. Kadar protein yang berlebihan pada pakan akan dibuang menjadi amoniak, tetapi jika tubuh masih memerlukan nutrisi berupa glukosa atau lemak maka protein dapat diubah menjadi glukosa atau lemak (Almatsier, 2005 dan Hariati, 1989). Selain itu kandungan lemak pada cacing tubifex ini sangat tinggi. Lemak yang tinggi diduga dapat menyebabkan penyimpanan lemak pada Lobster Air Tawar yang dapat menurunkan konsumsi pakan yang berpengaruh terhadap pertumbuhan (Zonneveld et al., 1991).

Nilai frekuensi molting Lobster Air Tawar yang dilaporkan (Hakim, 2008) sebesar 1,27 kali lebih rendah dibandingkan dengan penelitian ini 2,75-4,25 kali. Hal ini diduga karena (Hakim, 2008) dalam penelitiannya menggunakan pakan dengan kandungan protein $24 \%$. Sedangkan dalam penelitian ini menggunakan pakan dengan kandungan protein $38,08-65,5 \%$. Hal ini sesuai dengan pernyataan Manomaitis (2001), yang menyarankan bahwa benih Lobster Air Tawar dengan bobot lebih dari $1 \mathrm{~g}$ hendaknya diberi pakan dengan kandungan protein 30\% yang berfungsi untuk mempercepat pertumbuhan secara maksimal.

Nilai frekuensi molting Lobster Air Tawar yang dilaporkan (Hakim, 2009) sebesar 6,33 kali lebih tinggi dibandingkan dengan penelitian ini 2,75-4,25 kali. Hal ini disebabkan karena (Hakim, 2009), dalam penelitiannya menggunakan Lobster Air Tawar ukuran 2,5 $\mathrm{cm}$. Sedangkan dalam penelitian ini menggunakan Lobster Air Tawar dengan ukuran $5 \mathrm{~cm}$. Hal ini sesuai dengan pernyataan Merrick (1993), frekuensi pergantian karapak akan semakin lambat dengan pertambahan umur, pada juvenil terjadi setiap 10 hari, sedangkan setelah dewasa terjadi 4-5 kali setahun, ketika sudah menjadi induk dan pernah memijah biasanya melakukan molting 1-2 kali setahun.

Berdasarkan analisis variansi frekuensi molting dan pertumbuhan mutlak Lobter Air Tawar antar perlakuan sama-sama tidak berbeda nyata dimana $F$ hitung $<F$ tabel. Data selengkapnya dapat dilihat pada (Lampiran 2 dan 4). Pertumbuhan Lobster Air Tawar akan ditandai dengan proses pergantian cangkang yang dikenal dengan istilah molting. Dengan frekuensi molting Lobster Air Tawar yang sering, maka pertumbuhannya juga akan baik. Semakin baik pertumbuhannya, maka semakin 


\section{Agrisaintifika \\ Jurnal Ilmu-Ilmu Pertanian Vol. 4, No. 2, 2020}

sering Lobster Air Tawar berganti cangkang. Frekuensi molting Lobster Air Tawar meningkat maka pertumbuhannya juga ikut meningkat, tetapi apabila frekuensi molting Lobster Air Tawar menurun maka pertumbuhannya juga ikut menurun. Hal ini sesuai dengan pernyataan Ahvenharju (2007), bahwa Lobster Air Tawar hanya bisa tumbuh melalui molting.

Berdasarkan hasil penelitian ini nilai frekuensi molting dan pertumbuhan mutlaknya lebih tinggi dibandingkan dengan yang dilaporkan Hakim (2008). Hakim (2008) melaporkan nilai frekuensi molting sebanyak 1,27 kali dan pertumbuhannya sebesar $0,73 \mathrm{~g}$. Sedangkan dalam penelitian ini frekuensi molting sebanyak 2,75-4,25 kali dan pertumbuhannya sebesar 2,54-3,99 g. Selain itu frekuensi molting dan pertumbuhan Lobter Air Tawar penelitian ini juga lebih tinggi dibandingkan dengan yang dilaporkan Putri (2008). Putri (2008) melaporkan frekuensi molting sebanyak 2,73 kali dan pertumbuhannya sebesar 2,24 g. Sedangkan dalam penelitian ini frekuensi molting sebanyak $2,75-4,25$ kali dan pertumbuhannya sebesar 2,54-3,99 g.

\section{Sintasan Lobster Air Tawar}

Analisis Variansi menunjukan hasil yang tidak berbeda nyata dimana $F$ hitung $<F$ tabel. Nilai sintasan yang diperoleh pada masingmasing perlakuan diduga tidak disebabkan secara langsung oleh perbedaan persentase pakan tubifex dan komersial, tetapi disebabkan karena kanibalisme. Hal ini sesuai pernyataan Wiyanto dan Hartono, (2003) bahwa menurunnya tingkat sintasan dari larva Lobster Air Tawar dapat disebabkan oleh sifat kanibal yang dimiliki oleh Lobster Air Tawar sejak masih benih. Wie (2006) juga menambahkan bahwa, Lobster Air Tawar termasuk binatang yang memiliki sifat kanibal. Berdasarkan pengamatan, kematian Lobster Air Tawar selama penelitian terjadi pada saat mengalami molting. Lobster Air Tawar yang sedang melakukan tahap molting sangat lemah dan rentan terhadap serangan sesamanya dan mengeluarkan cairan pelicin (feromone) yang aromanya dapat memancing Lobster Air Tawar lain untuk memangsanya (Iskandar, 2003 dan Setiawan, 2006). Selain kanibalisme kematian Lobster Air Tawar juga disebabkan oleh ketidakmampuannya dalam melakukan molting secara sempurna. Tingkat sintasan Lobster Air Tawar dipengaruhi oleh ketinggian air, tingkat kepadatan, jenis pakan, ukuran pakan, dan kualitas air (Messer dan Rouse, 1997). Menurut Jones dan Rescue (2000), sintasan dipengaruhi oleh kondisi lingkungan, parasit, jumlah populasi, kemauan menyesuaikan diri dengan lingkungan, ketersediaan pakan, umur, dan penanganan selama pemeliharaan.

Sintasan Lobster Air Tawar yang dilaporkan (Hakim, 2009) sebesar 80,0093,33\% lebih tinggi dibandingkan dengan nilai sintasan penelitian ini $30-45 \%$. Hal ini disebabkan karena Hakim dalam penelitiannya menggunakan sistem EDU (Extreme Density Unit), sehingga dapat menghindari kanibalisme, karena setiap Lobster Air Tawar dipelihara pada masing-masing botol yang berbeda. Sedangkan dalam penelitian ini dalam satu akuarium berisi 5 ekor Lobster Air Tawar. Nilai sintasan Lobster Air Tawar yang dilaporkan Mukti et al., (2009) sebesar 94,5\% juga lebih tinggi dibandingkan dengan nilai sintasan penelitian ini 30-45\%. Hal ini diduga karena oksigen terlarut dalam penelitian ini kurang mendukung kehidupan Lobster Air Tawar yaitu sebesar 4,2-4,6 ppm, sedang Mukti et al., (2009) dalam penelitiannya melaporkan kandungan oksigen terlarutnya sebesar 5-7 ppm.

\section{SIMPULAN}

Pemberian pakan tubifex dan komersial dengan persentase yang berbeda tidak berpengaruh terhadap frekuensi molting dan sintasan Lobster Air Tawar. Tidak ditemukan persentase pakan tubifex dan komersial yang tepat untuk menghasilkan frekuensi molting dan sintasan yang baik. 


\section{DAFTAR PUSTAKA}

Affandi, R., Tang, U. M. 2002. Fisiologi Hewan Air. Universitas Riau Press, Riau.

Ahvenharju, T. 2007. Food Intake, Growth and Social Interactions of Signal Crayfish, Pacifastacus leniusculus (Dana). Dissertation. Fishery Science, Finnish Game and Fisheries Research Institute, Evo Game and Fisheries Research, Helsinki.

Almatsier, S. 2005. Prinsip Dasar Ilmu Gizi. Gramedia Pustaka Utama, Jakarta.

Effendi, M. I. 1997. Biologi Perikanan. Yayasan Pustaka Nusatama, Yogyakarta.

Gunawan. 2007. Pengaruh Perbedaan Bobot dan Temperatur Media Pemeliharaan terhadap Pemanfaatan Pakan Pada Lele Dumbo (Clarias gariepinus).Tesis. Program Pascasarjana Magister Biologi. Universitas Jenderal Soedirman, Purwokerto.

Hakim, R. R. 2008. Addition of Calcium with Different Dose to Succes of Red Claw (cherax quadricarinatus) Gastrolisation. Proceeding ofInternational Reseach Seminar and Exhibition. Research Center of Muhamadiyah Malang, Malang.

Hakim, R. R. 2009. Penambahan Kalsium pada Pakan untuk Meningkatkan Frekuensi Molting Lobster Air Tawar (Cherax quadricaritanus). Laporan Penelitian. Fakultas Peternakan Perikanan. Universitas Muhamadiyah Malang, Malang.

Hariati, A. M. 1989. Makanan Ikan. NUFFIC/UNIBRAW/LUW/FISH Fisheries Project. Universitas Brawijaya, Malang.

Iskandar, T. 2003. Budidaya Lobster Air Tawar. Agro Media Pustaka, Jakarta.

Jones, C. M., I.M,Ruscoe. 2000. Assessment of Stocking Size and Density in the Production of Red Claw Crayfish, Cherax quadricarinatus (Von Martens)
(Decapoda : Parastacidae), Cultured Under Earthen Pond Condition. Elsevier. Aquaculture, Australia.

Lukito, A, S. Prayugo, S. 2007. Panduan Lengkap Lobster Air Tawar. Penebar Swadaya, Jakarta

Manomaitis, L. 2001. Assesment of the Crude Protein Requirrement of Juvenile Red Claw Crayfish (Cherax quadricarinatus). Thesis. Auburn University, USA.

Merrick, R. 1993. Fresh Water Crayfishes of New South Wales. Linnean Sociaty of New South Wales, Australia.

Messer, M. P., Rouse, D. B. 1997. Australian Red Claw Crayfish. Aquaculture, 244: 1 8.

Mukti, A. T., Shofy, M., Adde, E. 2009.

Pengaruh Penambahan Madu dalam Pakan Induk Jantan Lobter Air Tawar Red Claw (Cherax quadricarinatus) terhadap Rasio Jenis Kelamin Larva. Jurnal IImiah Perikanan dan Kelautan, 1 (1): 37-42.

Nainggolan, A. 2008. Ablasi terhadap Pertumbuhan Lobster Crayfish Cherax quadricarinatus Pada Wadah yang Terkontrol. Jurnal IImiah Satya Negara Indonesia, 1 (2): 27-35.

National Research Council (NRC). 1993. Nutrien Requirement of Fish. National Academy Press, Washington, USA.

Nystrom. P. 2002. Ecology, Biology of freshwater Crayfish. BlackWell Science, London.

Pinto, GF,and DB, Rouse. 1996. Growth and Survival of the Australian Red Claw Crayfish Cherax quadricarinatus at Three Densities in Earthen Ponds. Jurnal of The Worlds Aquaculture of society, 27: 187193.

Putri, D. K. 2008. Penambahan Kalsium Pakan pada Frekuensi Molting Lobster Air Tawar (Cherax quadricarinatus). Skripsi. 
Sarmin, et al. 2020

Fakultas Sains dan Teknik. Universitas Jenderal Soedirman, Purwokerto.

Rouse, D. B. 1977. Production of Austalian Red Claw Crayfish. Auburn University Alabama, USA.

Setiawan. 2006. Teknik Pembenihan dan Cara Cepat Pembesaran Lobster Air Tawar. PT. Agro Media Pustaka, Jakarta.

Setyogati, W. 2006. Memelihara Lobster Hias Si Capit Merah. PT Sinergi Pustaka Indonesia, Bandung.

Subandiyah, S., Satyani, D., Aliyah.2003. Pengaruh Subtitusi Pakan Alami (Tubifex sp.) dan Buatan terhadap Pertumbuhan Ikan Tilan Lurik Merah (Mastacembelus erythrotaenia Bleeker, 1850). Jurnal Iktiologi Indonesia 3 (2): 67-72.
Sukmajaya, Y., I. Suharjo. 2003. Lobster Air Tawar Komoditas Perikanan Prospektif. Agromedia Pustaka, Jakarta.

Webster, C. D, L.G, Goodgametiu, J. H, Tidwell, D. B. Rouse, 1994. Evaluation of Practical Feed Formulation with Differnt Protein Level for Juvenile Redclaw Crayfish (Cherax quadricarinatus). Transaction of the Kentucky Academy of Science, 55: 108-112.

Wie, K. L. C. 2006. Pembenihan Lobster Air Tawar Meraup Untung dari Lahan Sempit. Agromedia, Jakarta Selatan.

Wiyanto, R. H., Hartono. 2003. Lobster Air Tawar, Pembenihan dan Pembesaran. Penebar Swadaya, Jakarta.

Zonneveld, N., E.A,Huisman, J. H. Boon, 1991. Prinsip-prinsip Budidaya Ikan. Gramedia Pustaka Utama, Jakarta. 
Agrisaintifika

Jurnal Ilmu-Ilmu Pertanian

Vol. 4, No. 2, 2020

Sarmin, et al. 2020

\section{Lampiran 1}

Hasil rata-rata frekuensi molting Lobster Air Tawar selama 60 hari pemeliharaan.

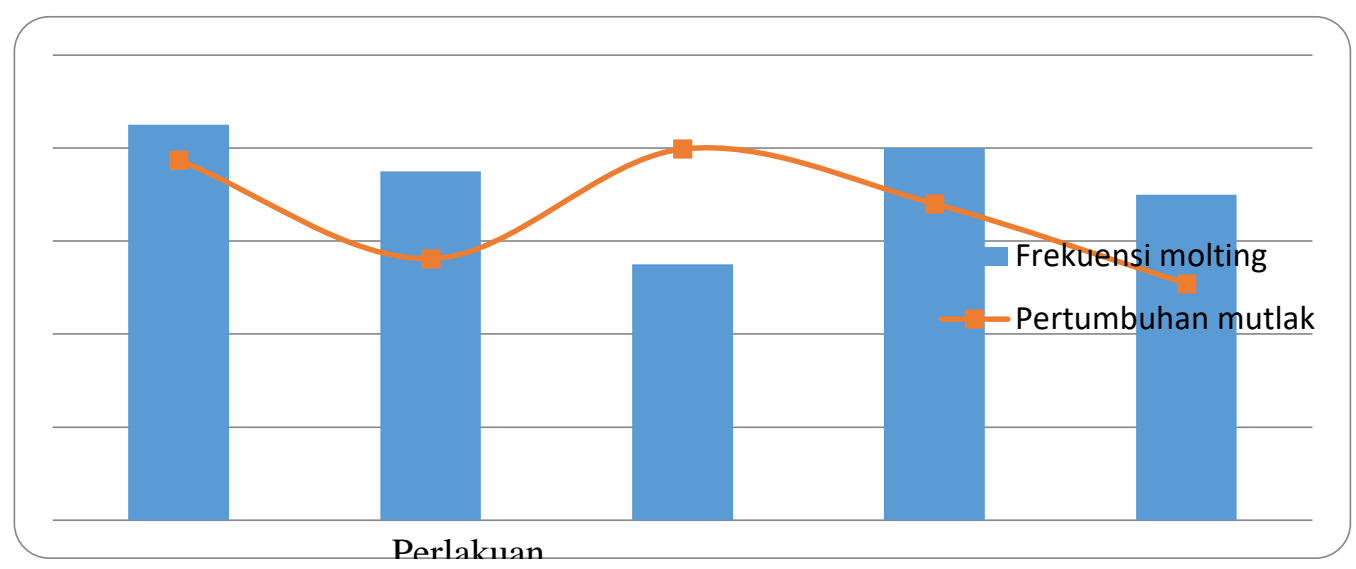

Gambar 2. Frekuensi molting dan pertumbuhan mutlak $(X \pm S D ; n=4)$ Lobster Air Tawar antar perlakuan, $\mathrm{P} 1=4,25 \pm 1,5$ kali; $\mathrm{P} 2=3,75 \pm 1,5$ kali; $\mathrm{P} 3=2,75 \pm 1,3$ kali; $\mathrm{P} 4=4 \pm 1,4$ kali; $\mathrm{P} 5=$ $3,5 \pm 1,3$ kali dan pertumbuhan mutlaknya, $P 1=3,87 \pm 1,99 \mathrm{~g} ; \mathrm{P} 2=2,81 \pm 0,12 \mathrm{~g} ; \mathrm{P} 3=3,99 \pm 0,32$ g; $P 4=3,40 \pm 1,61 \mathrm{~g} ; \mathrm{P} 5=2,54 \pm 0,93 \mathrm{~g}$.

\section{Lampiran 2}

Sintasan Lobster Air Tawar selama 60 hari pemeliharaan

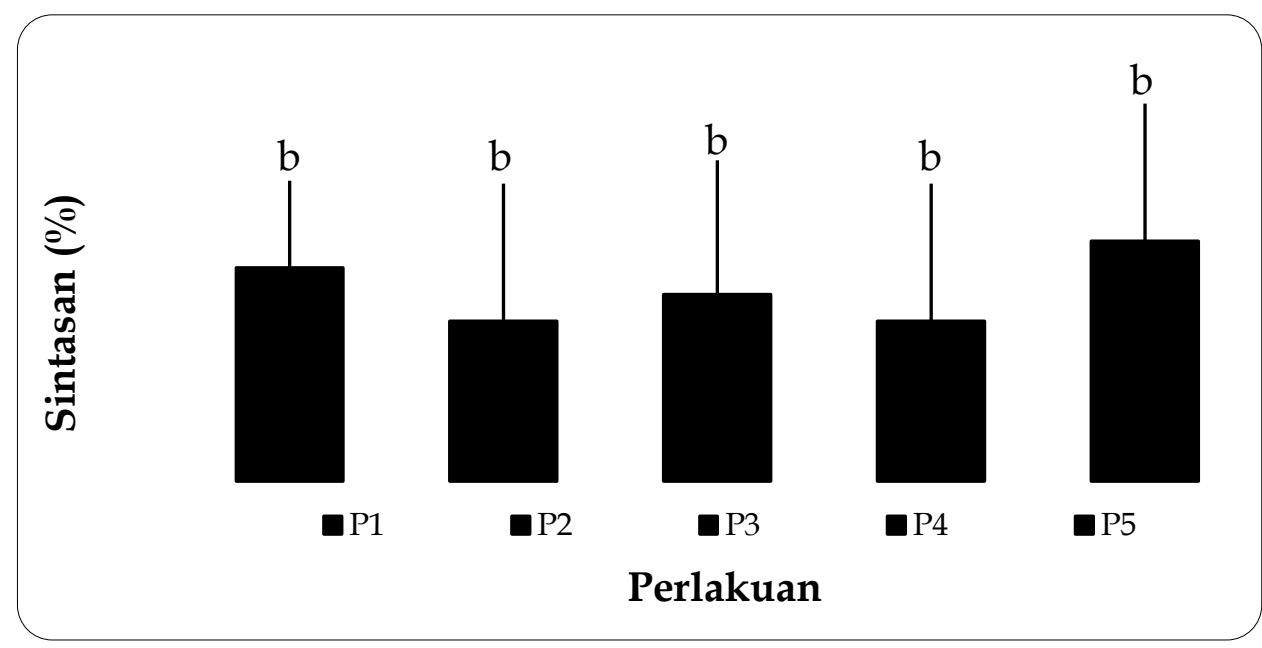

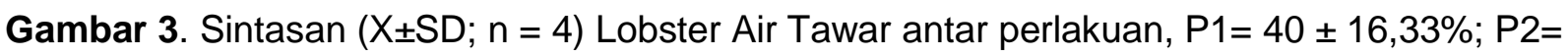
$30 \pm 25,82 \% ; P 3=35 \pm 25,17 \% ; P 4=30 \pm 25,82 \%$; $P 5=45 \pm 25,82 \%$. Huruf yang sama pada masing-masing perlakuan menunjukan tidak berbeda nyata. 